\title{
QUAL O DESTINO DOS PROGRAMAS 3 E 4 ? A PERGUNTA QUE NÃO QUER CALAR...
}

\author{
doi: 10.1590/S1807-59322010000100019
}

Clarissa O. da Silva

O editorial desta revista, publicado em agosto último ${ }^{1}$, trouxe-me incontrolável inquietação. E muito mais por deixar de fora uma questão que considero central neste hemisfério, do que propriamente pelo sinistro futuro que prefigura caso mudanças não ocorram (previsão de que compartilho). Trata-se de uma pergunta muito simples, e talvez exatamente por isto tenha passado despercebida a tantas cabeças muito mais experientes que a minha. Aqui vai, sem mais delongas: por que não existem linhas de fomento, na CAPES, destinadas somente a Programas com conceitos 3 e 4? Programas com conceitos 1 e 2, a CAPES fecha; 5, 6 e 7, vão bem, obrigado. E os 3 e 4 ? Me parecem que estão entregues à própria sorte.

Todos sabemos que do mesmo modo que o Journal of Citation Reports não julga trabalhos, mas periódicos, a avaliação da CAPES não julga pesquisador, mas Programas de pós-graduação. Ainda não quantifiquei o volume de trabalho necessário a um pesquisador produtivo de um Programa 3 e 4 para elevar o conceito de seu Programa a 5, que suspeito ser bem maior que aquele que PODE DEIXAR DE SER FEITO, por pesquisadores pouco produtivos de programas 6 e 7 para permanecerem com este conceito, simplesmente pelo fato de que esta conta depende do número total de pesquisadores em cada um destes programas (aqui chamado de massa crítica), e para que seja representativa do cenário nacional, deve considerar todos os casos, em cada área. Mas em poucas palavras, e sem lançar mão de argumentum ad hominem, quero de modo qualitativo dizer que a distribuição de talentos (bem como a falta deles...) é isotrópica no globo, mas a de oportunidades, não. Familiar neste hemisfério? Infelizmente sim. O CNPq é mais sensível a esta situação, na medida em que abre os editais ligados

Departamento de Química, Universidade Federal Rural do Rio de Janeiro - Seropédica/RJ.

Email: clarissa-dq@ufrrj.br à formação de recursos humanos (p.e. bolsa de doutorado "sandwich"), tanto a programas 5, 6 e 7, quanto a alunos de pesquisadores de Programas com conceito 3 ou 4 que tenham bolsa de produtividade em pesquisa. Sim, porque eles existem!

Que fique claro: não venho aqui propor uma sangria no sistema de fomento de Programas de pós-graduação produtivos. Isto seria de uma única vez, apregoar o atraso científico, negligenciar a necessidade que todos temos dos Programas produtivos, e subestimar a coerência da CAPES, que se esforça para colaborar com o crescimento da ciência no país. Mas muito humildemente, sem a experiência de quem há anos conhece o sistema, e com a esperança de quem por anos ainda permanecerá nele, gostaria de levantar outra possibilidade. A criação de linhas de fomento, poucas e bem menos ricas, para estimular o progresso de Programas nem tão ruins nem tão bons. Um fundo suplementar que Programas 3 e 4 pudessem pleitear com metas concretas e definidas, inclusive com cronograma que permitisse fazêlos subir degrau(s) de nível, quando alcançadas. Ninguém melhor que a própria CAPES para definir tudo isto, haja vista a enorme experiência acumulada ao longo de seus mais de 50 anos de existência. Fundamental seria que em tais editais, destinados a pesquisadores somente de Programas 3 e 4 existam rubricas específicas para participação de alunos em simpósios, congressos e escolas!

Existem com intenção semelhante editais lançados pela CAPES, como o Casadinho e o PROCAD, que associam Programas 3 e 4 àqueles 5, 6 ou 7. Mas infelizmente eles nem sempre alcançam a finalidade a que se propõem (como estão os Programas 3 e 4, cessado o intercâmbio? ). Isto acontece por várias razões, que vão desde a utilização somente da infra-estrutura dos Programas mais bem conceituados por aqueles menos conceituados, que usam os primeiros como simples prestadores de serviços, até a baixa prioridade que esta interação tem para grupos de 
Programas 5, 6 e 7, não justa, mas justificadamente. Custa alcançar estes conceitos! E como o tempo é finito, interações mais produtivas são mais eficazes neste propósito, afinal no DataCapes o item "produtividade" vale mais que aquele "solidariedade", não?

Estes editais são muito importantes, mas sozinhos não são suficientes para desenvolver o crescimento de Programas 3 e 4 . É necessário que ALÉM deles, haja outros que confiram mais independência a Programas 3 e 4, até mesmo porque em muitos casos, como no PROCAD, é necessário um número mínimo de pesquisadores e grupos, requisito mais facilmente atendido por Programas melhor conceituados, pois os menos, geralmente padecem não pela falta de qualidades individuais, mas pelo fato desta estar diluída numa também reduzida massa crítica.

Sem a implementação de políticas de fomento (não de avaliação!!) diferenciadas, não haverá desenvolvimento distribuído. Simplesmente observaremos um decaimento exponencial para a curva que descreve conceito versus número de Programas de pós-graduação com um dado conceito, ao lugar de uma desejável gaussiana, centrada em 5. E este perfil muito se deve à concentração de grande massa de doutores em pouquíssimos centros! Obviamente a amostragem tem qualidade magnificada quando acontece num ensemble maior, não guardando relação direta com capacidades individuais.

E ouso ainda destacar o momento estratégico em que esta pergunta vem formulada: com as novas contratações ocorridas em universidades federais por conta da reestruturação e expansão de que trata o REUNI, os percentuais de ampliação dos quadros de professores efetivos certamente são maiores em Instituições menores que em grandes centros. Ou seja, está chegando em Instituições menores mais gente, proporcionalmente, que em Instituições maiores. E é exatamente nestas Instituições menores que se encontra a maior parte dos Programas de pós-graduação com conceitos 3 e 4. Das duas uma: ou esperamos que com este aumento de contingente, a massa crítica de pesquisadores produtivos em Programas 3 e 4 aumente com o tempo, sempre através de um embate (cheio de coragem, estratégia e dignidade espartanas) destes com pesquisadores de centros mais desenvolvidos, nos MESMOS editais, ou seremos testemunhas de um agonizante deperecimento de recursos humanos.

Haveria ainda uma terceira possibilidade, com final mais feliz para a maior parte, que seria o estabelecimento de linhas de fomento específicas para este contingente.

Em economias desenvolvidas as Instituições são sólidas porque crescem com a contribuição das pessoas que por elas passam. Por isto encerro esta carta, com um apelo à CAPES e ao Ministério da Educação, que têm a faca e o queijo na mão, para que dêem fim à expectativa que precede a definição da trajetória da lâmina que paira sobre a cabeça de Programas de pós-graduação 3 e 4. Que ela corte o queijo.

\section{REFERENCE}

1. Rocha-e-Silva M. Clinics. 2009; 64:721-4. 